\title{
PERIPHERAL NEUROPATHY ELECTROPHYSIOLOGICAL SCREENING IN CHILDREN WITH CELIAC DISEASE
}

\author{
Sedat IȘIKAY' ${ }^{\star}$, Nurgül IȘIKAY ${ }^{2}$, Halil KOCAMAZ ${ }^{3}$ and Samil HIZLI ${ }^{4}$
}

\begin{abstract}
Background - The involvement of the peripheral nervous system in children with celiac disease is particularly rare. $\boldsymbol{O b}$ jective - The aim of this study was to assess the need for neurophysiological testing in celiac disease patients without neurological symptoms in order to detect early subclinical neuropathy and its possible correlations with clinical and demographic characteristics. Methods - Two hundred and twenty consecutive children with celiac disease were screened for neurological symptoms and signs, and those without symptoms or signs were included. Also, patients with comorbidities associated with peripheral neuropathy or a history of neurological disease were excluded. The remaining 167 asymptomatic patients as well as 100 control cases were tested electro-physiologically for peripheral nervous system diseases. Motor nerve conduction studies, including F-waves, were performed for the median, ulnar, peroneal, and tibial nerves, and sensory nerve conduction studies were performed for the median, ulnar, and sural nerves with $\mathrm{H}$ reflex of the soleus muscle unilaterally. All studies were carried out using surface recording electrodes. Normative values established in our laboratory were used. Results - Evidence for subclinical neuropathy was not determined with electrophysiological studies in any of the participants. Conclusion - In this highly selective celiac disease group without any signs, symptoms as well as the predisposing factors for polyneuropathy, we did not determine any cases with neuropathy. With these results we can conclude that in asymptomatic cases with celiac disease electrophysiological studies are not necessary. However, larger studies with the electrophysiological studies performed at different stages of disease at follow-ups are warranted.
\end{abstract}

HEADINGS - Celiac disease. Peripheral nervous system diseases. Electrophysiological phenomena. Child.

\section{INTRODUCTION}

Neurologic complications such as epilepsy, ataxia, neuropathy and headache/migraine are estimated to occur in $10 \%$ of patients who affected with celiac disease (CD) but the involvement of the peripheral nervous system in children with $\mathrm{CD}$ is not frequent ${ }^{(14)}$. The neuropathy associated with CD usually manifests as sensory neuropathy in the form of distal sensory loss, paresthesias, and imbalance ${ }^{(7)}$. Rarely, rapidly progressing syndrome like acute inflammatory demyelinating polyneuropathy, mononeuritis multiplex, pure motor neuropathy, and autonomic dysfunction have also been reported in association with celiac disease or anti-gliadin/anti-endomysial antibodies ${ }^{(3,5)}$. Neurological examination may reveal loss of large fiber sensory modalities, mild distal muscle weakness, reduced or absent muscle stretch reflexes, and an ataxic gait ${ }^{(14)}$.

The aim of this study was to examine the presence of possible neuropathy electrophysiologically in CD patients without any clinical neurological symptoms and signs in order to detect early abnormalities and discuss whether proper electrophysiological screening is required or not in asymptomatic celiac disease patients. In other terms, we aimed to determine the presence of possible preclinical neuropathy in children with $C D$.

\section{METHODS}

This prospective study included 220 children between the ages of 5 and 17 years, who were diagnosed as having CD at a Pediatric Gastroenterology Outpatient Clinic between September 2012 and August 2014 and 100 control cases who were not having any signs or symptoms of celiac disease and were also negative for anti-tissue transglutaminase antibodies Ig A and Ig G. All children were asked for the presence of symptoms of neuropathy and neurological

Declared conflict of interest of all authors: none

Disclosure of funding: no funding received

${ }^{1}$ Department of Pediatric Neurology, Gaziantep Children's Hospital, Gaziantep, Turkey. ${ }^{2}$ Department of Anesthesiology, Gaziantep University Faculty of Medicine, Gaziantep, Turkey: ${ }^{3}$ Department of Pediatric Gastroenterology, Gaziantep Children's Hospital, Gaziantep, Turkey; ${ }^{4}$ Department of Pediatric Gastroenterology, Yıldıım Beyazıt University Faculty of Medicine, Ankara, Turkey

Correspondence: Ass. Prof. Ședat Ișikay. Department of Pediatric Neurology, Gaziantep Children’s Hospital, 27500, Sehitkamil, Gaziantep, Turkey. E-mail: dr.sedatisikay@ mynet.com 
examination was performed to all children by the same pediatric neurologist at Pediatric Neurology outpatient clinic. Patients with comorbidities associated with polyneuropathy (diabetes, vitamin deficiency, such as B12 or folate, history of prolonged metronidazole exposure, history of thyroid disease) were excluded.

The remaining 186 patients and 100 control cases were subjected to a complete clinical neurological examination by a specialized neurologist. Patients with known neurological complications or overt clinical neurological symptoms or signs (muscle weakness, sensory disturbances or abnormalities in touch, pain, vibration or joint position sense, or deep tendon reflex abnormalities) were also excluded. The remaining 167 patients and 100 control cases were examined electrophysiologically using standard procedures and the results were evaluated according to the American Academy of Neurology Protocol for the diagnosis of Distal Symmetrical Polyneuropathy and Practice Parameter ${ }^{(8,10)}$.

A Nihon Kohden device (Nihon Kohden Corporation, Tokyo, Japan) was used. Limb temperature was tested and maintained between $31^{\circ} \mathrm{C}$ and $34^{\circ} \mathrm{C}$. Motor nerve conduction studies (NCS), including F-waves, were performed for the median, ulnar, peroneal, and tibial nerves, and sensory NCS were performed for the median, ulnar, and sural nerves with $\mathrm{H}$ reflex of the soleus muscle unilaterally. All studies were carried out using surface recording electrodes. Normative values established in our laboratory were used. Nerve conduction abnormalities include slowing of conduction velocity, conduction block, decrease of sensory or motor amplitude, and prolongation or temporal dispersion of the F-wave.

Polyneuropathy can be diagnosed when two or more abnormalities are detected at nonentrapment sites and it is classified as axonal or demyelinating if there is an am- plitude or a velocity abnormality, respectively. Data on the demographic and clinical characteristics of patients were recorded. Blood tests were performed for full blood count, serum glucose, B12 and folate level, liver and renal function, and thyroid functions.

The study was approved by the Ethics Committee of our Institution and informed consent of all patients are obtained from their parents.

\section{Statistical analysis}

Statistical analysis were performed using SPSS v17.0 for Windows (SPSS, Inc., Chicago, IL). Continuous variables are expressed as means \pm standard deviation (SD), whereas categorical variables are presented as absolute values and percentages. Differences between continuous variables were analyzed by unpaired Student's $t$-test, and differences between categorical variables were analyzed using the chi square test. A $P$-value of $<0.05$ was considered statistically significant.

\section{RESULTS}

Of the 220 patients examined, 167 were eligible for this prospective, cross-sectional study, on the basis of the inclusion criteria. Totally 167 patients (88 women and 79 men; mean age 9.23 years, range $1-16$ years) and 100 control cases (52 women and 48 men; mean age 9.83 years, range 3-17 years) were included in the study. Mean disease period of the patients was $2.96 \pm 2.84$ years in celiac group. Among those cases in celiac group, 19 of them were new-diagnosed cases starting gluten free diet.

The demographic and clinical characteristics of the participants included in the study are summarized in Table 1. Alanine transferase and Aspartate transferase levels were

TABLE 1. General characteristics and laboratory findings of participants

\begin{tabular}{lccc}
\hline & Celiac disease $(\mathrm{n}=167)$ & Control group $(\mathrm{n}=100)$ & $\boldsymbol{P}$ \\
\hline Age (years) & $9.23 \pm 3.96$ & $9.83 \pm 3.57$ & 0.21 \\
AST & $33.21 \pm 9.16$ & $17.91 \pm 11.34$ & 0.003 \\
ALT & $25.93 \pm 10.86$ & $13.24 \pm 9.21$ & 0.002 \\
ALP & $195.85 \pm 65.72$ & $192.76 \pm 72.80$ & 0.74 \\
Albumin & $4.15 \pm 0.33$ & $4.21 \pm 0.41$ & 0.81 \\
Hemoglobine (mg/dL) & $10.90 \pm 1.60$ & $12.47 \pm 1.10$ & 0.001 \\
MCV & $72.08 \pm 8.63$ & $78.73 \pm 5.34$ & 0.001 \\
RDW & $16.41 \pm 3.78$ & $13.29 \pm 1.91$ & 0.001 \\
Iron & $53.17 \pm 37.89$ & $58.54 \pm 30.83$ & 0.41 \\
Iron binding capacity & $339.95 \pm 84.34$ & $314.85 \pm 65.16$ & 0.72 \\
Vitamin B12 & $356.66 \pm 137.19$ & $352.29 \pm 160.14$ & 0.88 \\
Folic acid & $7.42 \pm 3.68$ & $9.49 \pm 2.81$ & 0.002 \\
Ferritin & $14.06 \pm 13.54$ & $33.41 \pm 22.80$ & 0.001 \\
Phosphorus & $4.44 \pm 0.52$ & $4.85 \pm 0.41$ & 0.78 \\
Platelet & $370.63 \pm 177.68$ & $296.89 \pm 89.60$ & 0.043 \\
\hline
\end{tabular}

AST: aspartate amino transferase; ALT: alanine amino transferase; ALP: alkaline phosphatase; MCV: mean corpuscular volume; RDW: red cell distribution width. The data are presented as mean \pm standard deviation. 
statistically significantly higher than the control cases in celiac group. On the other hand, hemoglobin, mean corpuscular volume, ferritin and folic acid levels were statistically significantly lower in celiac group compared with the control cases.

Neurological examination (cranial nerves evaluation, motor and sensory testing, deep tendon and plantar reflexes) indicated no abnormalities in all cases. The sensory and motor nerve conduction results of all participants are shown in Tables 2 and 3. The sensory and motor nerve conduction results were within normal limits in all patients examined. None of the examined patients had any evidence of large-fiber neuropathy. Moreover, there was not any statistically significant difference between the motor and sensory nerve conduction results of patients and control cases.

TABLE 2. Motor nerve conduction results of celiac disease patients

\begin{tabular}{|c|c|c|c|}
\hline & Celiac disease $(n=167)$ & Control group $(n=100)$ & $P$ \\
\hline \multicolumn{4}{|c|}{ Distal latency } \\
\hline Median & $2.78 \pm 1.18$ & $2.88 \pm 1.48$ & 0.55 \\
\hline Ulnar & $2.35 \pm 1.03$ & $2.36 \pm 1.18$ & 0.94 \\
\hline Tibial & $2.84 \pm 1.12$ & $2.94 \pm 1.33$ & 0.49 \\
\hline Peroneal & $2.76 \pm 1.12$ & $2.77 \pm 1.26$ & 0.92 \\
\hline \multicolumn{4}{|l|}{ Amplitude } \\
\hline Median & $10.65 \pm 4.19$ & $11.15 \pm 4.67$ & 0.36 \\
\hline Ulnar & $10.80 \pm 4.51$ & $11.74 \pm 4.64$ & 0.10 \\
\hline Tibial & $14.97 \pm 6.94$ & $14.72 \pm 7.77$ & 0.79 \\
\hline Peroneal & $4.10 \pm 4.69$ & $3.76 \pm 2.57$ & 0.51 \\
\hline \multicolumn{4}{|c|}{ Conduction velocity } \\
\hline Median & $58.64 \pm 7.46$ & $58.63 \pm 7.10$ & 0.98 \\
\hline Ulnar & $63.87 \pm 7.17$ & $62.43 \pm 7.03$ & 0.10 \\
\hline Tibial & $56.06 \pm 7.96$ & $57.52 \pm 9.83$ & 0.18 \\
\hline Peroneal & $57.39 \pm 7.68$ & $57.78 \pm 8.18$ & 0.69 \\
\hline \multicolumn{4}{|l|}{ F-wave } \\
\hline Median & $20.95 \pm 3.06$ & $21.18 \pm 2.80$ & 0.53 \\
\hline Ulnar & $20.59 \pm 3.85$ & $21.16 \pm 3.87$ & 0.24 \\
\hline Tibial & $33.64 \pm 6.91$ & $34.76 \pm 6.62$ & 0.19 \\
\hline Peroneal & $32.93 \pm 6.22$ & $34.18 \pm 5.94$ & 0.10 \\
\hline
\end{tabular}

Values are expressed as mean \pm S.D. Amplitude is expressed in $\mathrm{mV}$. Conduction velocity is expressed in $\mathrm{m} / \mathrm{s}$.

TABLE 3. Sensory nerve conduction results of celiac disease patients

\begin{tabular}{|c|c|c|c|}
\hline \multicolumn{4}{|l|}{ Amplitude } \\
\hline Ulnar & $30.15 \pm 18.12$ & $32.99 \pm 20.31$ & 0.24 \\
\hline Sural & $14.16 \pm 7.87$ & $14.67 \pm 7.68$ & 0.61 \\
\hline Ulnar & $56.92 \pm 9.30$ & $57.62 \pm 7.13$ & 0.52 \\
\hline Sural & $53.84 \pm 7.73$ & $54.55 \pm 7.20$ & 0.45 \\
\hline \multicolumn{4}{|l|}{ Latency } \\
\hline Median & $2.66 \pm 1.43$ & $2.65 \pm 1.42$ & 0.96 \\
\hline Ulnar & $2.16 \pm 0.39$ & $2.20 \pm 0.44$ & 0.51 \\
\hline Soleus & $22.35 \pm 2.21$ & $26.05 \pm 2.51$ & 0.158 \\
\hline
\end{tabular}

Values are expressed as mean \pm S.D. Amplitude is expressed in $\mathrm{mV}$. Conduction velocity is expressed in $\mathrm{m} / \mathrm{s}$. 


\section{DISCUSSION}

Although, the extraintestinal manifestations compromise a wide spectrum of neurologic conditions that have been classically associated with $\mathrm{CD}$, the involvement of the peripheral nervous system in children with $\mathrm{CD}$ is $\operatorname{rare}^{(9)}$. In this study, we aimed to determine the presence of preclinical peripheral neuropathy among patients with celiac disease and in fact we aimed to define the necessity of electrophysiological screening in asymptomatic cases with celiac disease. Among 167 celiac disease patients and 100 control cases without any symptoms and with normal neurological examinations; none of them revealed any abnormalities in electrophysiological studies. In the light of these data it can be suggested that; neurological examination is adequate to determine the presence of neuropathy and electrophysiological studies are not warranted in asymptomatic cases with CD.

Peripheral nervous system involvement in children with $\mathrm{CD}$ has been reported in only few cases, previously. Recently, Boskovic and Stankovic reported a 15-year-old girl affected by $\mathrm{CD}$, who presented with an acute sensory-motor demyelinating peripheral polyneuropathy after accidental reintroduction of gluten in her diet ${ }^{(2)}$. Ruggieri et al. reported the long term follow-up of a girl $(0.1 \%)$ out of 835 children with $\mathrm{CD}$; developing acute demyelinating neuropathy after accidental reintroduction of gluten in her diet, with rapid disappearance of symptoms on a gluten-free regimen ${ }^{(17)}$. Similar with our study Cakir et al. tried to investigate whether early neurological abnormalities may be detected in children with $\mathrm{CD}$ and they reported two peripheral polyneuropathy documented with electromyography, and one prolonged latencies in somatosensory evoked potential in 27 children with CD and receiving gluten free $\operatorname{diet}^{(4)}$. Rigamonti et al. describe two patients with celiac disease in whom neuropathy presented with progressive weakness of the limbs and in both patients a gluten-free diet induced a significant improvement of muscle strength and neurophysiological abnormalities ${ }^{(16)}$.

The exact association of polyneuropathy with $\mathrm{CD}$ is not clear. In celiac disease patients subclinical peripheral neuropathy without electrophysiological changes demonstrated by lower pain threshold and reduced heat and touch sensations have been reported. However, since we excluded the cases with any neurological symptoms and signs in our study, we did not observe these symptoms ${ }^{(12)}$. In a study of Shen et al.; in the CD group $38.9 \%$ met criteria for polyneuropathy compared with $20.5 \%$ in the control group and the difference between two groups was statistically significant. They also reported that on multiple logistic regression analysis, the odds of PN after adjusting for age, gender, diabetes, vita$\min \mathrm{B} 12$ deficiency, and cancer history were increased for $\mathrm{CD}$ and they concluded that polyneuropathy is more often found in patients with $\mathrm{CD}$ than in the general population ${ }^{(18)}$. Nevertheless in this study, patients with predisposing factors such as vitamin deficiencies or any neurological signs and symptoms were not excluded.

Peripheral neuropathy can be caused by a variety of systemic diseases, toxins, medications, infections, and hereditary disorders ${ }^{(12)}$. Biopsy proven CD has been reported in $2.5 \%$ of all patients who were evaluated for neuropathy ${ }^{(6)}$. Although associated vitamin deficiencies or direct toxic effects of gliadin are also proposed; the action of antibodies on extra-intestinal tissue transglutaminase proteins, and pathogenic involvement of antiganglioside antibodies are the main hypotheses suggested for the association of these two diseases ${ }^{(11,13)}$.

Immunoglobulin $\mathrm{G}$ antibody reactivity to peripheral nerve antigens has been recorded in individuals with coeliac disease and peripheral neuropathy ${ }^{(1)}$. Tursi et al. evaluated 32 consecutive adult $\mathrm{CD}$ patients, for the presence of neurological damage (by clinical neurological evaluation and electrophysiological study) and antineuronal antibodies. They reported that at entry, $12(37.5 \%)$ of 32 patients showed signs and symptoms of neurological damage and Anti-GM1 antibodies were present in $5(41.6 \%)$ of those 12 patients ${ }^{(19)}$. Rashtak evaluated 51 patients with unexplained ataxia/neuropathy suspected to have gluten sensitivity for serum celiac-specific markers and determined that deamidated gliadin-IgA, deamidated gliadin-IgG, tissue transglutaminase-IgA, and anti-endomysial-IgA, were significantly more positive in ataxia/neuropathy patients with $\mathrm{CD}$ versus those without enteropathy ${ }^{(15)}$. In the same study the authors have also reported that 3 out of 10 patients with neuropathy improved on a gluten-free $\operatorname{diet}^{(15)}$.

In this study we excluded the cases with any symptoms or signs of polyneuropathy or any other neurological disease as the patients with polyneuropathy predisposing factors and this may be the main reason that we did not determine any cases with neuropathy. This high selection may be one of the limitations of this study by excluding the patients who might have neuropathy associated with the $\mathrm{CD}$, but at the same time it is a strength of this study because in fact we aimed to determine the necessity of screening for polyneuropathy in asymptomatic cases with CD not the prevalence of neuropathy. The second limitation may be the relatively small sample size since neuropathy is a rare condition in CD. Although our sample was not homogenous in terms of the disease age or gluten free diet period; the mean duration of the disease period was not long $(2.96 \pm 2.84$ years) and the subclinical polyneuropathy may be a manifestation of $\mathrm{CD}$ at later stages. A larger study with longer disease period of patients may be better to elucidate the association of preclinical polyneuropathy with $\mathrm{CD}$.

In conclusion, the association of $\mathrm{CD}$ with neuropathy has been reported before. In this highly selective CD group without signs, symptoms as well as the predisposing factors for polyneuropathy; we did not determine any cases with neuropathy. With these results; we can conclude that in asymptomatic cases with $\mathrm{CD}$ electrophysiological studies are not required. However, larger studies with the electrophysiological studies performed at different stages of disease with longer follow-ups are warranted.

\section{Authors' contributions}

Ișikay $\mathrm{S}$ : helped in finding patients and collected patient records. Ișikay $\mathrm{S}$ and other authors: helped in writing manuscript. 
Işikay S, Ișikay N, Kocamaz H, Hızlı S. Triagem eletrofisiológica de neuropatia periférica em crianças com doença celíaca. Arq Gastroenterol. 2015,52(2):134-8.

RESUMO - Contexto - O envolvimento do sistema nervoso periférico em crianças com doença celíaca é particularmente raro. Objetivo - O objetivo do presente estudo foi avaliar a necessidade de testes neurofisiológicos em pacientes com doença celíaca sem sintomas neurológicos, a fim de detectar neuropatia subclínica precoce e suas possíveis correlações com características clínicas e demográficas. Métodos - Duzentos e vinte crianças consecutivas com doença celíaca foram pesquisadas para os sinais e sintomas neurológicos, e foram incluídos somente aqueles sem sintomas ou sinais. Além disso, os portadores de comorbidades associadas à neuropatia periférica ou história de doença neurológica também foram excluídos. Os 167 pacientes assintomáticos, bem como 100 casos controles foram testados electrofisiologicamente para doenças do sistema nervoso periférico. Estudos de condução nervosa motora, incluindo ondas F foram realizados para os nervos medianos, ulnar, fibular e tibiais; realizaram-se estudos de condução sensorial para o nervo mediano, ulnar, e nervos surais com reflexo H do músculo sóleo unilateralmente. Todos os estudos foram realizados utilizando gravação por eletrodos de superfície. Foram usados valores normativos estabelecidos em nosso laboratório. Resultados - Não foi determinada evidência de neuropatia subclínica com estudos eletrofisiológicos em qualquer um dos participantes. Conclusão - Neste grupo altamente seletivo de pacientes com doença celíaca sem quaisquer sinais, sintomas, bem como os fatores predisponentes para a polineuropatia, não se determinou qualquer caso com neuropatia. Com estes resultados, pode-se concluir que, em casos assintomáticos com doença celíaca os estudos eletrofisiológicos não são necessários. No entanto, são necessários maiores estudos eletrofisiológicos realizados em diferentes fases da doença.

DESCRITORES - Doença celíaca. Doenças do sistema nervoso periférico. Fenômenos eletrofisiológicos. Criança.

\section{REFERENCES}

1. Alaedini A, Green PHR, Sander HW, Hays AP, Gamboa ET, Fasano A, et al. Ganglioside reactive antibodies in the neuropathy associated with celiac disease. J Neuroimmunol. 2002;127(1-2):145-8.

2. Boskovic A, Stankovic I. Axonal and demyelinating polyneuropathy associated with celiac disease. Indian Pediatr. 2014;51(4):311-2.

3. Brannagan TH 3rd, Hays AP, Chin SS, Sander HW, Chin RL, Magda P, et al. Small-fiber neuropathy/neuronopathy associated with celiac disease: skin biopsy findings. Arch Neurol. 2005;62(10):1574-8.

4. Cakir D, Tosun A, Polat M, Celebisoy N, Gokben S, Aydogdu S, et al. Subclinical neurological abnormalities in children with celiac disease receiving a gluten-free diet. J Pediatr Gastroenterol Nutr. 2007;45(3):366-9.

5. Chin RL, Sander HW, Brannagan TH, Green PH, Hays AP, Alaedini A, Latov N. Celiac neuropathy. Neurology. 2003;60(10):1581-5.

6. Chin RL, Latov N, Green PH, Brannagan TH 3rd, Alaedini A, Sander HW. Neurologic complications of celiac disease. J Clin Neuromuscul Dis. 2004;5(3):129-37.

7. Chin RL, Tseng VG, Green PH, Sander HW, Brannagan TH 3rd, Latov N. Multifocal axonal polyneuropathy in celiac disease. Neurology. 2006;66(12):1923-5.

8. England JD, Gronseth GS, Franklin G, Miller RG, Asbury AK, Carter GT, et al. Distal symmetric polyneuropathy: a definition for clinical research. report of the American Academy of Neurology, the American association of electrodiagnostic medicine, and the American Academy of physical medicine and rehabilitation. Neurology. 2005;64(2):199-207.

9. Gobbi G. Coeliac disease, epilepsy and cerebral calcifications. Brain Dev. 2005;27(3):189-200

10. Jablecki CK, Adary MT, Floeter MK, Miller RG, Quartly CA, Vennix MJ, Wilson JR. Practice parameter: electrodiagnostic studies in carpal tunnel syndrome. Report of the American Academy of Neurology, the American Association of Electrodiagnostic Medicine, and the American Academy of Physical Medicine and Rehabilitation. Neurology. 2002;58(11):1589-92.
11. Lerner A, Makhoul B, Eliakim R. Neurological manifestations of celiac disease in children, adults. Eur Neurol J. 2010;000:1-6.

12. Luostarinen L, Himanen SL, Luostarinen M, Collin P, Pirttilä T. Neuromuscular and sensory disturbances in patients with well treated coeliac disease. J Neurol Neurosurg Psychiatry. 2003;74(4):490-4.

13. Lytton S, Antiga E, Pfeiffer S, Matthias T, Szaflarska-Poplawska A, Ulaganathan VK, et al. Neo-epitope tissue transglutaminase autoantibodies as a biomarker of the glüten sensitive skin disease - Dermatitis herpetiformis. Clin Chim Acta 2013;415:346-9.

14. Nikpour S. Neurological manifestations, diagnosis, and treatment of celiac disease: A comprehensive review. Iran J Neurol. 2012;11(2):59-64.

15. Rashtak S, Rashtak S, Snyder MR, Pittock SJ, Wu TT, Gandhi MJ, Murray JA.. Serology of celiac disease in gluten-sensitive ataxia or neuropathy: role of deamidated gliadin antibody. J Neuroimmunol. 2011;230(1-2):130-4.

16. Rigamonti A, Magi S, Venturini E, Morandi L, Ciano C, Lauria G. Celiac disease presenting with motor neuropathy: effect of gluten free-diet. Muscle Nerve. 2007;35(5):675-7.

17. Ruggieri M, Incorpora G, Polizzi A, Parano E, Spina M, Pavone P. Low prevalence of neurologic and psychiatric manifestations in children with gluten sensitivity. J Pediatr. 2008;152(2):244-9.

18. Shen TC, Lebwohl B, Verma H, Kumta N, Tennyson C, Lewis S, et al. Peripheral neuropathic symptoms in celiac disease and inflammatory bowel disease. $\mathrm{J}$ Clin Neuromuscul Dis. 2012;13(3):137-45.

19. Tursi A, Giorgetti GM, Iani C, Arciprete F, Brandimarte G, Capria A, Fontana L. Peripheral neurological disturbances, autonomic dysfunction, and antineuronal antibodies in adult celiac disease before and after a gluten-free diet. Dig Dis Sci. 2006;51(10):1869-74.

Received 7/9/2014 Accepted 7/10/2014 